\title{
PRODUCTION OF THE MATERNAL PLACENTA IN RABBITS FOLLOWING ASPIRATION OF CONCEPTUSES
}

\author{
L. H. HOFFMAN AND J. DAVIES \\ Department of Anatomy, Vanderbilt University, School of Medicine, \\ Nashville, Tennessee 37203, U.S.A.
}

\section{(Received 15th December 1970)}

The induction of a decidual cell response in the rabbit uterus has been studied by numerous investigators since its discovery by Loeb (1908). Such a response results from traumatizing the uterine endometrium of pseudopregnant does or the sterile horn of unilaterally pregnant does by means of incisions (Loeb, 1908 ) or the insertion of threads (Courrier \& Kehl, 1930). A similar result is obtained using either thread trauma or the instillation of various chemical stimuli into the uterine lumen of ovariectomized oestrogen-progesteronemaintained does (Elton, 1966). Traumatic deciduomata in rabbits bear little resemblance to the decidua of a normal pregnancy with respect to gross morphology and size, although the same histological change, i.e. decidual cell response, occurs in both. Quantification of such deciduomal masses is difficult, perhaps the optimal criterion being that of glycogen content (Beasley \& Davenport, 1970). The best inducer of a decidual response in the rabbit is the blastocyst. We have observed that, if the blastocyst is allowed to remain in contact with the uterine endometrium throughout the period of attachment and early implantation, it can then be dispensed with and the maternal placenta will grow and differentiate in its absence.

New Zealand white rabbits were subjected to laparotomy under Nembutal anaesthesia on Days 7, 8 and 9 of gestation (Day of mating = Day 0). Each implantation site was exposed, a $23 \mathrm{G}$ needle inserted through the anti-mesometrial wall of the uterus and the contents displaced by repeated aspiration with Hanks' solution. When inspected on Day 16 of gestation, each former implantation site in the animals treated on Day 8 was represented by a fully formed maternal placenta, lacking any visible traces of foetus or trophoblast (P1. 1, Fig. 1). Histological examination confirmed the absence of viable trophoblast and demonstrated the similarity of the deciduae to those present in a normal pregnancy (Pl. 1, Fig. 2). Periodic acid-Schiff staining likewise confirmed the comparability of these structures with respect to glycogen distribution (Pl. 1, Fig. 3). These 'blastocyst-induced' deciduomata are somewhat smaller than the maternal placentae of control 16-day pregnant females (Table 1). Aspiration of the conceptuses on Day 7 resulted in a weak decidual reaction, while the females treated on Day 9 produced a smaller than normal decidua $(<0.5 \mathrm{~g})$ with a relatively deep luminal zone of necrotic trophoblast. The decidua was still present on Day 20, remarkably well preserved in gross form as well as histologically, but reduced in size. The fate of the decidual masses 
has not yet been studied beyond Day 20; however, it appears that degenerative changes have begun at the tissue level by this time. The lifespan of these deciduomata is apparently similar in length to those induced in the sterile horn of a unilateral pregnancy (25 days), but definitely greater than the lifespan of traumatic deciduomata induced during pseudopregnancy which disappear by 20 days (cf. DeFeo, 1967).

TABLE 1

COMPARISON OF LUTEAL AND DECIDUAL WEIGHTS BETWEEN DEGIDUALIZED, PREGNANT AND PSEUDOPREGNANT FEMALES

\begin{tabular}{|c|c|c|c|c|}
\hline & $\begin{array}{l}\text { No. of } \\
\text { females }\end{array}$ & $\begin{array}{l}\text { Mean decidual } \\
\text { weight }(g)\end{array}$ & $\begin{array}{l}\text { No. of } \\
\text { corpora lutea }\end{array}$ & $\begin{array}{c}\text { Mean luteal } \\
\text { weight } \pm \text { S.D. }(m g)\end{array}$ \\
\hline $\begin{array}{l}\text { Pseudopregnant } \\
\text { 16-day } \\
\text { 20-day }\end{array}$ & $\begin{array}{l}6 \\
5\end{array}$ & E & $\begin{array}{l}65 \\
45\end{array}$ & $\begin{array}{c}16 \cdot 5 \pm 2 \cdot 77 \\
8 \cdot 44 \pm 1 \cdot 63\end{array}$ \\
\hline $\begin{array}{l}\text { Pregnant } \\
\text { 16-day } \\
\text { 20-day }\end{array}$ & $\begin{array}{l}3 \\
6\end{array}$ & $\begin{array}{l}1.57 \\
1.46\end{array}$ & $\begin{array}{l}33 \\
58\end{array}$ & $\begin{array}{l}17 \cdot 53 \pm 1 \cdot 60 \\
18 \cdot 53 \pm 2 \cdot 85\end{array}$ \\
\hline $\begin{array}{l}\text { Decidualized* } \\
\text { 16-day } \\
\text { 20-day }\end{array}$ & $\begin{array}{l}4 \\
3\end{array}$ & $\begin{array}{l}0.98 \\
0.67\end{array}$ & $\begin{array}{l}37 \\
36\end{array}$ & $\begin{array}{l}16 \cdot 2 \pm 1 \cdot 81 \\
15 \cdot 8 \pm 2 \cdot 01 \dagger, \ddagger\end{array}$ \\
\hline
\end{tabular}

* Conceptus destruction carried out on Day 8.

† Significantly different from 20-day pseudopregnant $(P<0.01)$.

$\ddagger$ Not significantly different from 20 -day pregnant $(P>0 \cdot 25)$.

Our preliminary data, based on luteal weights (Table 1), indicate a level of luteal maintenance at 20 days which is greater than that of pseudopregnancy but less than pregnancy. This is supported by histological observations on the corpora lutea showing moderately well maintained corpora lutea in the ovary of decidualized females (Pl. 1, Fig. 4) as compared with the advanced luteal degeneration in the ovary of a 20-day pseudopregnant female (Pl. 1, Fig. 5). Evidence on the effect of 'massive decidualization' upon luteal maintenance has been lacking (DeFeo, 1967), although indications are that, in the absence of hormonal therapy, thread-induced deciduomata (Spies, Hilliard \& Sawyer, 1968) and those induced by uterine incisions (S. Beasley, personal communication) fail to support luteal life beyond the 16 days of pseudopregnancy.

The technique of obtaining extensive decidualization as described here offers a new tool for the investigation of utero-placental-ovarian relationships in the rabbit as well as for the study of the inductive phenomena associated with implantation.

This study was supported by NIH Grant HD-00971 and Postdoctoral Fellowship HD-36,050-03 from the USPHS.

\section{REFERENCES}

Beasley, S. S. \& Davenport, G. R. (1970) A study of the deciduoma of the pseudopregnant rabbit. Anat. Rec. 166, 276.

Courrier, R. \& Kehz, R. (1930) Le déciduome expérimental chez la lapine gestante. C. r. Séanc. Soc. Biol. 104, 1180. 

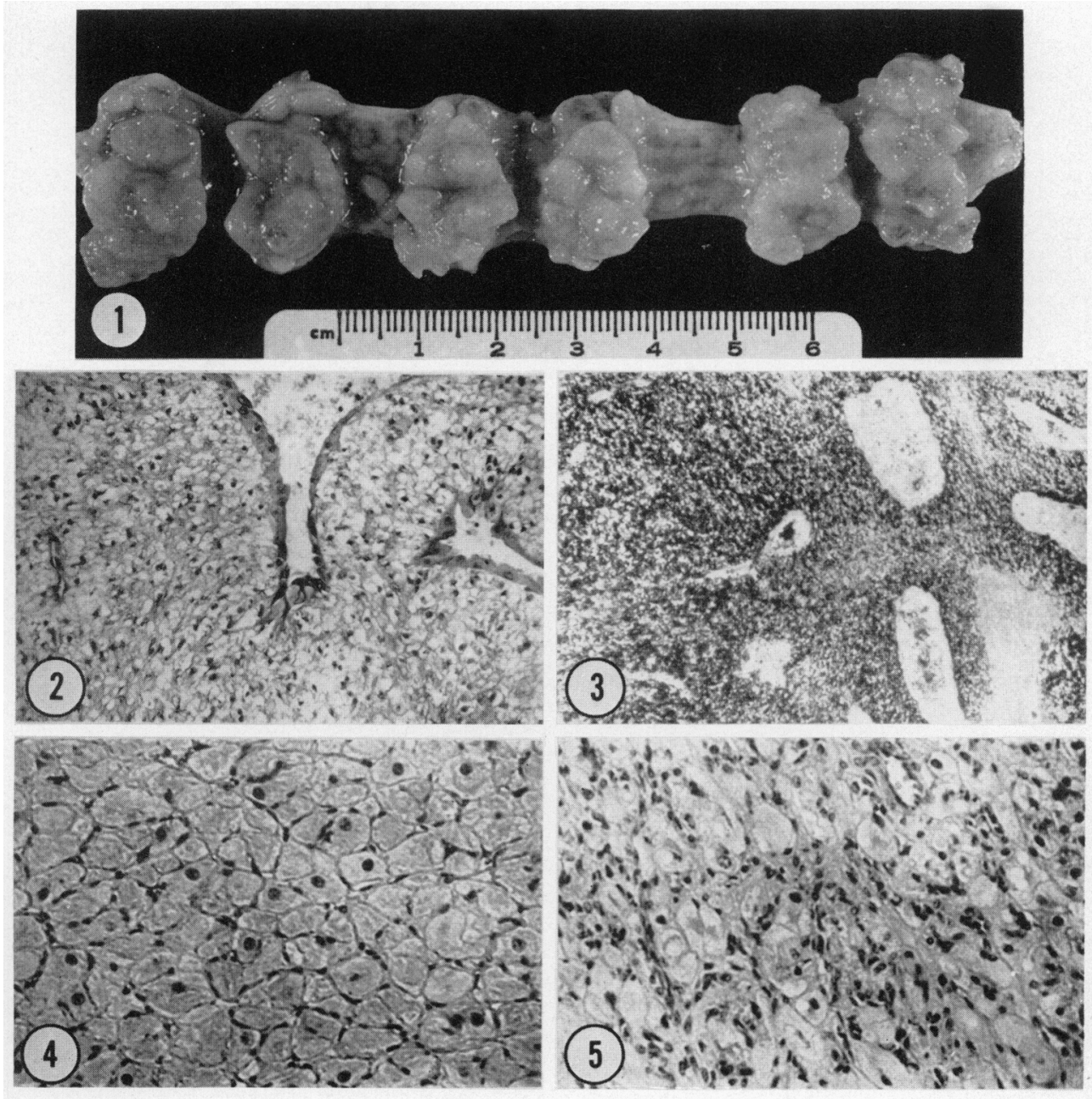

Fic. 1. Gross vicw of maternal placentac on Day 16 of gestation. 8 days after the destruction of conceptuses. The utcrine horn has been opened anti-mesometrially.

Fic. 2. Histological view of 'blastocyst-induced' decidua. The empty appearance of the colls is due to the dissolution of glycogen and lipid. H \& E. $\times 85$.

Fic. 3. Induced decidua preserved in Gendre's fixative and stained for glycogen. P.AS. $\times 31$.

FIG. 4. Well-maintained corpus lutcum from a decidualized female at Day 20 of gestation. Conceptuses aspirated on Day $8 . \mathrm{H} \& \mathrm{E} . \times 141$.

Fici. 5. Corpus luteum from a 20 -day pseudopregnant female. Nuclear pyknosis, cytoplasmic vacuolation, and the infiltration of connective tissue elements indicate that these luteal cells are degenerating. H \& E. $\times 141$. 
DeFeo, V. (1967) Decidualization. In: Cellular Biology of the Uterus. Ed. R. M. Wynn. AppletonCentury-Grofts, New York.

ELton, R. L. (1966) The decidual cell response in rabbits. Acta endocr., Copenh. 51, 543.

LOEB, L. (1908) The experimental production of the maternal part of the placenta in the rabbit. Proc. Soc. exp. Biol. Med. 5, 102.

Spies, H. G., Hilliard, J. \& SAWYer, C. H. (1968) Pituitary and uterine factors controlling regression of corpora lutea in intact and pseudopregnant rabbits. Endocrinology, 83, 291. 